\title{
Perbedaan Keragaman Pangan, Pola Asuh Makan, dan Asupan Zat Gizi Makro pada Balita dari Ibu Bekerja dan Ibu Tidak Bekerja
}

\section{Differences of Food Diversity, Child Feeding Patterns, and Macro Nutrition Intake in Children from Business Women and Housewife}

\author{
Hesti Permata Sari ${ }^{1}$, Lilis Permatasari ${ }^{1}$, Widya Ayu Kurnia Putri ${ }^{1}$
}

\begin{abstract}
ABSTRAK
Latar Belakang: Balita merupakan kelompok yang rentan mengalami permasalahan gizi. Pola asuh merupakan salah satu faktor yang mempengaruhi status gizi balita. Ibu yang bekerja di luar rumah memiliki lebih sedikit waktu bersama balita sehingga akan berdampak pada perhatian ibu terhadap pertumbuhan dan perkembangan balita, termasuk keragaman pangan, pola asuh makan, dan asupan zat gizi makro balita. Hasil penelitian di Padang menunjukkan bahwa malnutrisi pada anak memiliki resiko 1,3 kali lebih besar pada ibu yang bekerja.

Tujuan: Mengetahui perbedaan keragaman pangan, pola asuh makan, dan asupan zat gizi makro pada balita berdasarkan status pekerjaan ibu

Metode: Desain penelitian ini adalah observasional analitik dengan pendekatan cross sectional. Penelitian dilakukan pada ibu yang tinggal di perumahan dengan tingkat sosial ekonomi menengah di Kabupaten Banyumas. Sampel penelitian yaitu balita berusia 12-59 bulan sebanyak 78 balita, diambil menggunakan teknik total sampling. Data diuji statistik menggunakan uji $T$ independent.

Hasil: Hasil penelitian menunjukan tidak terdapat perbedaan keragaman pangan $(p=0,767)$, pola asuh makan $(p=0,605)$, asupan energi $(p=0,483)$, asupan protein $(p=0,806)$, asupan lemak $(p=0,787)$ dan asupan karbohidrat $(p=0,337)$ pada balita berdasarkan status pekerjaan ibu. Hal ini terjadi karena tingkat pendidikan dan ekonomi yang sama antara kedua kelompok. Kesimpulan: Tidak terdapat perbedaan keragaman pangan, pola asuh makan, dan asupan zat gizi makro pada balita berdasar status pekerjaan ibu
\end{abstract}

Kata Kunci: Keragaman Pangan, Pola Asuh Makan, Asupan Zat Gizi Makro, Ibu Bekerja

\section{ABSTRACT}

Background: Toddlers are a group that is vulnerable to experiencing nutritional problems. The role of caregivers is one of the one of the factors that influence nutritional status. Working mother especially who work outside house, have less time together with toddlers so that it will have an impact on mothers' attention to the growth and development of toddlers, food diversity, child feeding patterns, and macro-nutrient intake of toddlers. Research in Padang states that business women have a 1,3 times risk of experiencing malnutrition in children.

Purpose: To assess the differences in food diversity, child feeding patterns, and macro nutrient intake in toddlers from business women and housewife.

Methods: The design of this study was an observational analytic with cross sectional approach. The research was conducted on medium socioeconomic housing in Banyumas Regency. The sample are toddlers aged 12-59 months as many as 78 toddlers, taken using total sampling techniques. Data were statistically tested using independent $T$ tests.

Results: The results of study showed no differences in food diversity $(p=0.767)$, child feeding patterns $(p=0.605)$, energy intake $(p=0.483)$, protein intake $(p=0.806)$, fat intake $(p=0.787)$ and carbohydrate intake $(p=0.337)$ in toddlers from business women and housewife.

Conclusions: There were no differences in food diversity, child feeding patterns, and macro nutrient intake in toddlers from business women and housewife.

Keywords: Food Diversity, Child Feeding Patterns, Macro Nutrient Intake, Business Women

\author{
*Korespondensi: \\ hesti.sari@unsoed.ac.id \\ Hesti Permata Sari \\ ${ }^{1}$ Program Studi IImu Gizi, Fakultas IImu-ilmu Kesehatan, Universitas Jenderal Soedirman \\ Jl. Dr Soeparno No. 60, Karangwangkal, Purwokerto, Indonesia \\ Published by Universitas Airlangga and IAGIKMI
}




\section{PENDAHULUAN}

Usia balita merupakan salah satu kelompok usia yang rentan mengalami permasalahan gizi. Peningkatan angka kematian bayi dan anak, gangguan pertumbuhan dan perkembangan, serta penurunan produktifitas dan kualitas hidup balita merupakan beberapa akibat yang dapat ditimbulkan karena kekurangan gizi ${ }^{1}$. Hasil Riskesdas tahun 2018 menunjukan bahwa di Indonesia, prevalensi balita gizi kurang mencapai $13,8 \%$ dan balita gizi buruk mencapai 3,9\%. Balita sangat pendek sebanyak $11,5 \%$ dan $19,3 \%$ balita termasuk dalam kategori pendek $^{2}$. Prevalensi gizi kurang pada balita usia 0-59 bulan di Jawa Tengah sebesar $13,7 \%$ dan gizi buruk sebesar 3,1\%. Balita pendek sebesar 20,1\% dan balita sangat pendek $11,2 \%$. Balita di Kabupaten Banyumas yang mengalami gizi kurang dan gizi buruk prevalensinya mencapai $14,8 \%$ dan balita pendek serta sangat pendek mencapai $24,5 \%^{3}$.

Status gizi balita dipengaruhi oleh faktor penyebab langsung dan tidak langsung. Secara tidak langsung status gizi balita dipengaruhi oleh ketersediaan pangan, pola asuh ibu, sanitasi, dan pemanfaatan layanan kesehatan. Secara langsung status gizi balita dipengaruhi oleh asupan makan dan kondisi kesehatan balita ${ }^{4}$. Status gizi balita bergantung pada peran pengasuh, terutama ibu. Peran ibu dalam keluarga bergantung pada waktu yang dimiliki untuk berada di rumah. Menurut Badan Pusat Statistik Indonesia tahun 2019, tingkat partisipasi angkatan kerja perempuan selalu meningkat dari 55,04\% pada Februari 2017 menjadi 55,44\% pada Februari 2018, dan $55,50 \%$ pada Februari $2019^{5}$. Ibu bekerja memiliki waktu yang lebih sedikit untuk bersama dengan balita sehingga perhatian terhadap pertumbuhan dan perkembangan balita menjadi kurang ${ }^{6}$. Penelitian yang dilakukan di Padang menunjukan bahwa malnutrisi pada anak memiliki resiko 1,3 kali lebih besar pada ibu yang bekerja ${ }^{7}$.

Pola asuh ibu berhubungan dengan pemberiaan makan dan perawatan kesehatan balita ${ }^{8}$. Pemberian makan akan berpengaruh terhadap kecukupan asupan dan status gizi balita. Pemberian makan tidak hanya memperhatikan apa yang dimakan, tetapi juga sikap atau peran ibu untuk memperhatikan sikap balita ketika makan, serta mengenalkan berbagai jenis makanan kepada balita. Balita dengan pola asuh makan kurang tepat lebih banyak mengalami gizi kurang dibandingkan balita dengan pola asuh makan tepat ${ }^{9}$. Pola asuh makan dipengaruhi oleh status pekerjaan ibu. Ibu yang memiliki kegiatan diluar rumah untuk mendapatkan penghasilan dalam bentuk uang atau barang, baik dilakukan secara langsung atau tidak langsung dengan mengeluarkan energi dalam waktu tujuh jam selama enam hari kerja atau delapan jam selama lima hari kerja disebut ibu bekerja ${ }^{10}$. Balita dengan pola asuh makan baik pada ibu bekerja sebesar $38,1 \%$, sedangkan pada balita dari ibu tidak bekerja mencapai $65 \%{ }^{11}$.

Asupan zat gizi dapat dilihat secara kuantitas dan kualitas. Asupan zat gizi secara kuantitas dilihat melalui tingkat kecukupannya, sedangkan secara kualitas dilihat melalui keragaman pangan yang dikonsumsi. Keragaman pangan adalah banyaknya konsumsi pangan atau kelompok pangan dalam jangka waktu tertentu.
Konsumsi makanan yang beragam merupakan indikator tercapainya status gizi optimal dan salah satu upaya pencegahan kekurangan zat gizi ${ }^{12}$. Keragaman pangan yang rendah dapat meningkatkan resiko terjadinya masalah gizi seperti stunting, wasting, dan gizi buruk ${ }^{13}$. Keragaman pangan juga merupakan faktor resiko kejadian stunting paling banyak dibanding pola asuh makan dan panjang badan balita saat lahir ${ }^{14}$.

Asupan zat gizi secara kuantitas dapat dilihat dari tingkat kecukupan konsumsi zat gizi, baik mikro ataupun makro. Zat gizi makro berfungsi sebagai penyedia energi dan dibutuhkan tubuh dalam jumlah besar. Kebutuhan zat gizi makro yang tidak tercukupi dapat mengakibatkan beberapa masalah kesehatan. Rendahnya asupan energi dan protein pada balita akan meningkatkan resiko terjadinya kekurangan energi protein dan kekurangan energi kronis, serta gangguan pada pertumbuhan dan perkembangan balita ${ }^{15}$. Tingkat asupan lemak yang rendah dapat mengakibatkan gangguan hormone, penyerapan vitamin larut lemak, gangguan metabolisme zat gizi, dan penurunan massa tubuh. Zat gizi makro lainnya yang berpengaruh terhadap status gizi adalah karbohidrat. Asupan karbohidrat yang rendah menyebabkan pemecahan lemak tubuh dan asam amino menjadi energi, akibatnya tubuh akan kehilangan asam amino yang dibutuhkan untuk sintesis jaringan dan pertumbuhan balita. Selain itu, susunan syaraf dan otak hanya menggunakan glukosa sebagai sumber energi, sehingga kekurangan glukosa dan oksigen dapat menyebabkan kelainan pada syaraf dan kerusakan otak yang tidak dapat diperbaiki ${ }^{16}$. Ketidakseimbangan konsumsi zat gizi makro dalam jangka panjang dapat menyebabkan kehilangan berat badan karena berubahnya komposisi jaringan dan massa tubuh ${ }^{17}$. Berdasarkan latar belakang tersebut, peneliti bermaksud melakukan penelitian untuk mengetahui keragaman pangan, pola asuh makan, dan asupan zat gizi makro pada balita dilihat dari perspektif status pekerjaan ibu.

\section{METODE}

Penelitian ini berupa penelitian observasional analitik dengan pendekatan cross sectional. Penelitian dilakukan di Perumahan Grand Safira Karangsalam dan Perumahan Saphire Karang Sempu Purwokerto, Kabupaten Banyumas pada Bulan Maret 2020. Populasi penelitian yaitu balita berusia 12 - 59 bulan dari ibu bekerja dan ibu tidak bekerja. Usia balita dikategorikan menjadi tiga kelompok, yaitu 0-1 tahun (usia bayi), 2-3 tahun (usia batita), dan 4-5 tahun (usia pra-sekolah) ${ }^{18}$. Responden dimasukkan ke kelompok ibu bekerja bila responden bekerja diluar rumah selama tujuh jam selama enam hari kerja atau delapan jam selama lima hari kerja dan meninggalkan balitanya dengan pengasuh selama hari kerja. Responden dimasukan kedalam kategori ibu tidak bekerja bila responden tidak memiliki pekerjaan lain selain mengurus balitanya. Responden yang memiliki bekerja dari rumah seperti pedagang daring, atapun ibu rumah tangga yang memiliki pekerjaan lain namun bukan sebagai pekerjaan utama kami ekslusi. Jumlah sampel penelitian sebanyak 78 sampel yang ditentukan dengan teknik total sampling. 
Penelitian dilakukan dengan melakukan kunjungan rumah balita sebanyak dua kali. Kunjungan pertama dilakukan untuk melakukan pengambilan data karakteristik responden, pola asuh makan, serta asupan makan balita pada hari libur. Kunjungan kedua dilakukan untuk melakukan pengambilan data asupan makan balita yang kedua yaitu pada hari kerja. Pengambilan data karakteristik pendidikan ibu, pekerjaan ibu, dan pendapatan keluarga dilakukan dengan wawancara. Data pendidikan ibu dikategorikan menjadi dua kategori yaitu pendidikan menengah yaitu ibu yang berlatar pendidikan SMA dan tinggi yaitu ibu yang berlatar pendidikan tinggi meliputi pendidikan diploma, strata satu, dua, maupun tiga. Pekerjaan ibu dikategorikan menjadi dua, yaitu karyawan swasta dan pegawai negeri sipil (PNS). Data pendapatan keluarga yaitu total pendapatan dalam keluarga dalam satu bulan. Pengambilan data karakteristik status gizi dilakukan dengan pengukuran langsung. Pengukuran berat badan menggunakan timbangan bayi untuk responden yang berusia kurang dari dua tahun dan timbangan digital untuk responden yang berusia lebih dari dua tahun. Data status gizi didapat dengan analisis Z-Score BB/U dan kategorikan berdasarkan kategori permenkes nomor 2 tahun 2020. Pengambilan data pola asuh makan menggunakan Child Feeding Questionare. Data konsumsi makan balita diperoleh melalui kuesioner food recall $2 \times 24$ jam dengan mewawancarai ibu balita, asisten rumah tangga, dan atau nenek yang memberikan makan kepada balita. Pengambilan data konsumsi makan dilakukan sebanyak dua kali, yaitu pada hari kerja (senin-jum'at) dan hari libur (sabtu dan minggu), kemudian diperoleh hasil rata-rata asupan zat gizi makro balita. Data keragaman pangan diperoleh menggunakan kuesioner Dietary Diversity Score dengan melihat hasil recall $2 \times 24$ jam. Data penelitian dianalisis menggunakan analisis distribusi frekuensi untuk data karakteristik responden, dan uji Independent T-Test untuk menganalisis perbedaan kedua kelompok. Penelitian telah mendapat persetujuan Komisi Etik Penelitian Kesehatan Fakultas Ilmu-ilmu Kesehatan UNSOED dengan nomor 072/EC/KEPK/III/2020.

\section{HASIL DAN PEMBAHASAN}

Tabel 1. Karakteristik Responden

\begin{tabular}{|c|c|c|}
\hline \multirow{2}{*}{ Karakteristik Responden } & \multicolumn{2}{|c|}{ Frekuensi } \\
\hline & $\mathbf{n}$ & $\%$ \\
\hline \multicolumn{3}{|l|}{ Usia Balita } \\
\hline $12-23$ bulan & 23 & 29,5 \\
\hline $24-35$ bulan & 19 & 24,5 \\
\hline $36-47$ bulan & 18 & 23,0 \\
\hline $48-59$ bulan & 18 & 23,0 \\
\hline Total & 78 & 100,0 \\
\hline \multicolumn{3}{|l|}{ Status Gizi Balita } \\
\hline Gizi Kurang (BB/U -3 SD sampai <-2 SD) & 2 & 2,6 \\
\hline Gizi Baik (BB/U -2 SD sampai 2 SD) & 70 & 89,7 \\
\hline Gizi Lebih (BB/U >2 SD) & 6 & 7,7 \\
\hline Total & 78 & 100,0 \\
\hline \multicolumn{3}{|l|}{ Status Pekerjaan Ibu } \\
\hline Ibu Bekerja & 33 & 42,3 \\
\hline Ibu Tidak Bekerja & 45 & 57,7 \\
\hline Total & 78 & 100,0 \\
\hline \multicolumn{3}{|l|}{ Pendidikan Ibu } \\
\hline Menengah (SMA) & 10 & 12,8 \\
\hline Tinggi (D3, S1, S2) & 68 & 87,2 \\
\hline Total & 78 & 100,0 \\
\hline \multicolumn{3}{|l|}{ Pekerjaan Ibu } \\
\hline Ibu Rumah Tangga & 45 & 57,7 \\
\hline Karyawan Swasta & 25 & 32,0 \\
\hline PNS & 8 & 10,3 \\
\hline Total & 78 & 100,0 \\
\hline \multicolumn{3}{|l|}{ Total Penghasilan Keluarga pada Ibu Bekerja } \\
\hline Rp $1.750 .000,00$ s.d $<$ Rp $3.500 .000,00$ & 2 & 6,0 \\
\hline Rp 3.500.000,00 s.d Rp 5.000.000,00 & 5 & 15,2 \\
\hline$>$ Rp 5.000.000,00 & 26 & 78,8 \\
\hline Total & 33 & 100,0 \\
\hline \multicolumn{3}{|l|}{ Total Penghasilan Keluarga pada Ibu Tidak Bekerja } \\
\hline $\operatorname{Rp} 1.750 .000,00$ s.d $<$ Rp $3.500 .000,00$ & 9 & 20,0 \\
\hline Rp $3.500 .000,00$ s.d Rp $5.000 .000,00$ & 9 & 20,0 \\
\hline$>\operatorname{Rp} 5.000 .000,00$ & 27 & 60,0 \\
\hline Total & 45 & 100,0 \\
\hline
\end{tabular}

Distribusi karakteristik responden disajikan pada Tabel 1. Tabel 1 menunjukan sebagian besar usia responden berkisar antara 12-59 bulan. Masa bayi hingga usia 2 tahun merupakan periode kritis pada masa pertumbuhan atau disebut periode emas (golden period). Pertumbuhan pada masa bayi lebih pesat dari masa batita 
dan pra-sekolah, akan tetapi pada masa batita dan pra sekolah terjadi peningkatan aktivitas yang lebih tinggi, sehingga pemenuhan kebutuhan zat gizi sangat penting untuk mendukung aktivitas dan tumbuh kembangnya.

Status gizi respoden menurut indikator $\mathrm{BB} / \mathrm{U}$ menunjukan bahwa balita dengan status gizi normal sebanyak $89,7 \%$, status gizi kurang sebanyak 2,6\%, dan status gizi lebih sebanyak $7,7 \%$. BB/U merupakan perbandingan $B B$ relatif dengan umur balita. Indeks BB/ $U$ menggambarkan status gizi baik, gizi kurang (underweight), gizi buruk (severely underweight), dan gizi lebih $^{19}$.

Status pekerjaan ibu terbagi dalam dua kategori, yaitu $42,3 \%$ ibu balita merupakan ibu bekerja dan $57,7 \%$ lainnya ibu tidak bekerja. Tingkat pendidikan ibu sebagian besar $\mathrm{S1}$, yaitu sebanyak $61,5 \%$. Tabel 1 juga menunjukan sebagian besar penghasilan keluarga per bulan yaitu >Rp 5.000.000,00. Pendidikan, jenis pekerjaan dan jumlah penghasilan keluarga merupakan indikator konvensional yang dapat digunakan untuk mengukur tingkat sosial ekonomi ${ }^{20}$. Kemampuan keluarga dalam memberikan perhatian yang lebih terhadap asupan dan status gizi balita akan meningkat pada keluarga dengan kehidupan ekonomi yang lebih baik. Pengetahuan ibu yang cukup terkait gizi dan pengaturan makan balita juga dapat menghindari kejadian gizi kurang pada balita ${ }^{21}$.

Tabel 2.Keragaman Pangan, Pola Asuh Makan, Dan Asupan Zat Gizi Makro Balita

\begin{tabular}{|c|c|c|c|c|}
\hline \multirow{2}{*}{ Karakteristik } & \multicolumn{2}{|c|}{ Ibu Bekerja } & \multicolumn{2}{|c|}{ Ibu Tidak Bekerja } \\
\hline & $\mathbf{n}$ & $\%$ & $\mathbf{n}$ & $\%$ \\
\hline \multicolumn{5}{|l|}{ Keragaman Pangan } \\
\hline Sedang & 24 & 72,7 & 30 & 66,7 \\
\hline Baik & 9 & 27,3 & 15 & 33,3 \\
\hline Total & 33 & 100,0 & 45 & 100,0 \\
\hline \multicolumn{5}{|l|}{ Pola Asuh Makan } \\
\hline Tepat & 33 & 100,0 & 45 & 100,0 \\
\hline Kurang Tepat & 0 & 0,0 & 0 & 0,0 \\
\hline Total & 33 & 100,0 & 45 & 100,0 \\
\hline \multicolumn{5}{|l|}{ Asupan Energi } \\
\hline Defisit berat (<70\% AKGI) & 1 & 3,0 & 3 & 6,7 \\
\hline Defisit sedang (70-79\% AKGI) & 2 & 6,1 & 7 & 15,6 \\
\hline Defisit ringan (80-89\% AKGI) & 4 & 12,2 & 8 & 17,8 \\
\hline Normal (90-119\% AKGI) & 18 & 54,5 & 17 & 37,8 \\
\hline Lebih ( $\geq 120 \%$ AKGI) & 8 & 24,2 & 10 & 22,2 \\
\hline Total & 33 & 100,0 & 45 & 100,0 \\
\hline \multicolumn{5}{|l|}{ Asupan Protein } \\
\hline Defisit berat (<70\% AKGI) & 0 & 0,0 & 0 & 0,0 \\
\hline Defisit sedang (70-79\% AKGI) & 1 & 3,0 & 0 & 0,0 \\
\hline Defisit ringan (80-89\% AKGI) & 0 & 0,0 & 0 & 0,0 \\
\hline Normal (90-119\% AKGI) & 2 & 6,1 & 0 & 0,0 \\
\hline Lebih ( $\geq 120 \%$ AKGI) & 30 & 90,9 & 45 & 100,0 \\
\hline Total & 33 & 100,0 & 45 & 100,0 \\
\hline \multicolumn{5}{|l|}{ Asupan Lemak } \\
\hline Defisit berat (<70\% AKGI) & 2 & 6,1 & 2 & 4,4 \\
\hline Defisit sedang (70-79\% AKGI) & 2 & 6,1 & 1 & 2,2 \\
\hline Defisit ringan (80-89\% AKGI) & 2 & 6,1 & 6 & 13,3 \\
\hline Normal (90-119\% AKGI) & 7 & 21,1 & 13 & 28,9 \\
\hline \multicolumn{5}{|l|}{ Asupan Lemak } \\
\hline \multicolumn{5}{|l|}{ Lebih ( $\geq 120 \%$ AKGI) } \\
\hline Total & 33 & 100,0 & 45 & 100,0 \\
\hline \multicolumn{5}{|l|}{ Asupan Karbohidrat } \\
\hline Defisit berat (<70\% AKGI) & 7 & 21,2 & 14 & 31,1 \\
\hline Defisit sedang (70-79\% AKGI) & 8 & 24,2 & 7 & 15,6 \\
\hline Defisit ringan (80-89\% AKGI) & 5 & 15,2 & 7 & 15,6 \\
\hline Normal (90-119\% AKGI) & 10 & 30,3 & 15 & 33,3 \\
\hline Lebih ( $\geq 120 \%$ AKGI) & 3 & 9,1 & 2 & 4,4 \\
\hline Total & 33 & 100,0 & 45 & 100,0 \\
\hline
\end{tabular}

Tabel 2 menunjukan pola asuh makan balita seluruhnya termasuk kategori tepat. Keragaman pangan balita dari ibu bekerja sebagian besar $(72,7 \%)$ termasuk kategori sedang, sementara pada balita dari ibu tidak bekerja hanya sebesar $66,7 \%$ yang termasuk kategori sedang. Asupan energi dan karbohidrat balita termasuk dalam kategori normal, sedangkan asupan protein dan lemak termasuk dalam kategori lebih. 
Tabel 1. Frekuensi Makan Balita

\begin{tabular}{|c|c|c|c|c|}
\hline & \multicolumn{2}{|c|}{ Ibu Bekerja } & \multicolumn{2}{|c|}{ Ibu Tidak Bekerja } \\
\hline & $n$ & $\%$ & $n$ & $\%$ \\
\hline \multicolumn{5}{|l|}{ Makan utama } \\
\hline$\geq 3 x$ sehari & 24 & 72,7 & 31 & 68,9 \\
\hline$<3 x$ sehari & 9 & 27,3 & 14 & 31,1 \\
\hline Total & 33 & 100,0 & 45 & 100,0 \\
\hline \multicolumn{5}{|l|}{ Selingan } \\
\hline$\geq 2 x$ sehari & 15 & 45,5 & 24 & 53,3 \\
\hline$<2 x$ sehari & 18 & 54,5 & 21 & 46,7 \\
\hline Total & 33 & 100,0 & 45 & 100,0 \\
\hline \multicolumn{5}{|l|}{ Susu formula } \\
\hline Rata-rata & \multicolumn{2}{|c|}{3} & \multicolumn{2}{|c|}{2,62} \\
\hline$\geq$ rata-rata & 21 & 63,6 & 21 & 46,5 \\
\hline$<$ rata-rata & 12 & 36,4 & 24 & 53,5 \\
\hline Total & 33 & 100,0 & 45 & 100,0 \\
\hline \multicolumn{5}{|l|}{ Sayur } \\
\hline$\geq 3 x$ sehari & 4 & 12,1 & 3 & 6,7 \\
\hline$<3 x$ sehari & 29 & 87,9 & 42 & 93,3 \\
\hline Total & 33 & 100,0 & 45 & 100,0 \\
\hline \multicolumn{5}{|l|}{ Buah } \\
\hline$\geq 2 x$ sehari & 3 & 9,1 & 3 & 6,6 \\
\hline$<2 x$ sehari & 30 & 90,9 & 42 & 93,4 \\
\hline Total & 33 & 100,0 & 45 & 100,0 \\
\hline
\end{tabular}

Tabel 3 menunjukan bahwa ibu bekerja lebih banyak memberikan makanan utama dan susu formula dibanding ibu tidak bekerja. Konsumsi sayur dan buah juga lebih sering diberikan oleh ibu bekerja kepada balitanya.

Tabel 4. Proporsi Susu Formula dalam Pemenuhan Kebutuhan Zat Gizi Makro Balita

\begin{tabular}{lcc}
\hline \multirow{2}{*}{ Zat Gizi Makro } & \multicolumn{2}{c}{ \% Pemenuhan Zat Gizi Makro dari Susu Formula } \\
\cline { 2 - 3 } & Ibu Bekerja & Ibu Tidak Bekerja \\
\hline Energi & $35,2 \%$ & $28,7 \%$ \\
Protein & $71,7 \%$ & $65,4 \%$ \\
Lemak & $45,5 \%$ & $35,3 \%$ \\
Karbohidrat & $26,8 \%$ & $21,2 \%$ \\
\hline
\end{tabular}

Tabel 4 menunjukan bahwa susu formula memberikan sumbangan besar terhadap total kebutuhan zat gizi makro balita. Sumbangan energi yang diperoleh dari susu formula pada balita dari ibu bekerja sebesar $35,2 \%$, protein $71,7 \%$, lemak $45,5 \%$, dan karbohidrat $26,8 \%$ dari total kebutuhan harian. Sumbangan energi dari susu formula pada balita dari ibu tidak bekerja sebesar $28,7 \%$, protein $65,4 \%$, lemak $35,3 \%$, dan karbohidrat $21,2 \%$ dari total kebutuhan harian.

Tabel 5. Analisis Perbedaan Keragaman Pangan, Pola Asuh Makan, dan Asupan Zat Gizi Makro Balita

\begin{tabular}{|c|c|c|c|c|}
\hline Variabel & Minimal & Maksimal & Rata-rata & p 95\% \\
\hline \multicolumn{5}{|c|}{ Keragaman Pangan Konsumsi } \\
\hline \multicolumn{5}{|l|}{ Pangan Balita (Skor) } \\
\hline Ibu bekerja & 3 & 7,5 & 5,2 & \multirow{2}{*}{0,767} \\
\hline Ibu tidak bekerja & 3 & 7 & 5,3 & \\
\hline \multicolumn{5}{|l|}{ Pola Asuh Makan (Skor) } \\
\hline Ibu bekerja & 44 & 60 & 50,7 & \multirow{2}{*}{0,605} \\
\hline Ibu tidak bekerja & 37 & 58 & 50,1 & \\
\hline \multicolumn{5}{|c|}{ Tingkat Kecukupan Zat Gizi Makro (Dalam \% AKGI) } \\
\hline \multicolumn{5}{|c|}{ Tingkat Kecukupan Energi } \\
\hline Ibu bekerja & 59,3 & 196,1 & 108,8 & \multirow{2}{*}{0,483} \\
\hline Ibu tidak bekerja & 55,8 & 202,9 & 104,1 & \\
\hline \multicolumn{5}{|c|}{ Tingkat Kecukupan Protein } \\
\hline Ibu bekerja & 77 & 360,5 & 209,8 & \multirow[b]{2}{*}{0,806} \\
\hline Ibu tidak bekerja & 122,6 & 411,5 & 206,4 & \\
\hline Tingkat Kecukupan Le & & & & \\
\hline
\end{tabular}




\begin{tabular}{lcccc} 
Ibu bekerja & 49,5 & 203,3 & 130,6 & 0,787 \\
$\begin{array}{l}\text { Ibu tidak bekerja } \\
\text { Tingkat Kecukupan }\end{array}$ & 64,8 & 240,7 & 128 & \\
$\begin{array}{l}\text { Karbohidrat } \\
\text { Ibu bekerja }\end{array}$ & & & \\
$\quad$ Ibu tidak bekerja & 45,2 & 168,6 & 86,4 & 0,337 \\
\hline
\end{tabular}

\section{Keragaman Pangan Balita berdasarkan Status Pekerjaan Ibu}

Kualitas konsumsi makan balita dapat digambarkan melalui keragaman pangan dengan melihat sembilan jenis kelompok makanan yang dikonsumsi balita dalam sehari. Tabel 2 menunjukan bahwa keragaman pangan balita dari ibu bekerja sebagian besar $(72,7 \%)$ termasuk kategori sedang, sementara pada balita dari ibu tidak bekerja hanya sebesar $66,7 \%$ yang termasuk kategori sedang. Tabel 3 menunjukan bahwa ibu bekerja lebih banyak memberikan makanan utama dan susu formula dibanding ibu tidak bekerja. Konsumsi sayur dan buah juga lebih sering diberikan oleh ibu bekerja kepada balitanya.

Berdasarkan uji $\mathrm{T}$ Independent yang telah dilakukan, diperoleh nilai $p=0,767$ atau $p>0,05$ sehingga secara statistik tidak terdapat perbedaan keragaman pangan yang signifikan. Hal tersebut dikarenakan rata-rata total pendapatan keluarga serta tingkat pendidikan ibu pada ibu bekerja maupun ibu tidak bekerja hampir homogen lebih dari rata-rata kebanyakan.

Keragaman pangan balita dipengaruhi oleh status sosial ekonomi keluarga ${ }^{22}$. Keragaman pangan akan meningkat seiring dengan meningkatnya pendapatan keluarga. Penelitian di Brazil juga menyebutkan bahwa keragaman pangan sangat ditentukan oleh faktor sosial ekonomi, pengeluaran pangan, dan pendapatan ${ }^{23}$. Pengetahuan ibu yang cukup tentang gizi juga dapat mempengaruhi pemilihan makanan serta dapat menyusun menu makanan yang beragam sesuai kebutuhan ${ }^{24}$

Tabel 5 menunjukkan bahwa keragaman pangan balita dari ibu bekerja memiliki rata-rata skor 5,2 dan 5,3 untuk balita dari ibu tidak bekerja dengan skor keragaman pangan maksimal sebesar 9. Kecenderungan konsumsi pangan balita lebih dominan pada kelompok makanan pokok berpati, sayur dan buah selain sayuran hijau dan sumber vitamin A, ikan dan daging, telur, serta susu dan produk susu. Konsumsi pangan untuk kelompok sayuran hijau, sayur dan buah sumber vitamin A, jeroan, serta kelompok polong, kacang dan bijibijian lebih rendah dibandingkan kelompok pangan lainnya.

Tabel 3 menggambarkan bahwa sebagian besar balita dari ibu bekerja $(87,9 \%)$ dan ibu tidak bekerja $(93,3 \%)$ mengkonsumsi sayur $<3 x$ sehari. Konsumsi buah pada balita sebagian besar $<2 x$ sehari, yaitu sebanyak $90,9 \%$ pada balita dari ibu bekerja dan 93,4\% pada balita dari ibu tidak bekerja. Jumlah tersebut lebih rendah dari anjuran konsumsi sayur dan buah menurut Kementerian Kesehatan RI yaitu 3-4 porsi sayur dan 2-3 porsi buah setiap harinya. Sayur dan buah memiliki kandungan vitamin, mineral, serat, dan zat fitokimia yang berperan dalam meningkatkan daya tahan tubuh, kecerdasan intelektual dan sosial, proses pertumbuhan dan perkembangan balita serta sistem hormon dalam tubuh. Konsumsi sayur dan buah yang rendah dapat meningkatkan resiko penyakit degeneratif pada saat dewasa ${ }^{25}$.

Balita lebih menyukai mengkonsumsi makanan tinggi kalori dibandingkan sayur dan buah ${ }^{26}$. Lingkungan keluarga dan lingkungan luar akan mempengaruhi pembentukan pola makan pada balita. Kebiasaan makan yang diajarkan kepada balita sejak dini akan lebih resisten untuk mengalami perubahan, sehingga kebiasaan atau pola makan yang baik termasuk pengenalan aneka ragam makanan penting untuk dilakukan sejak usia balita ${ }^{27}$. Pengenalan aneka ragam makanan perlu diperkenalkan sejak dini agar dapat membiasakan pola makan sehat pada balita.

Pola makan balita akan menyesuaikan dengan kelompoknya. Pembentukan pola makan seimbang pada balita harus dimulai dari keluarga ${ }^{28}$. Kebiasaan makan pada masa balita juga akan terbawa sampai dewasa, sehingga apabila kebiasaan mengkonsumsi sayur dan buah tidak diterapkan sejak dini maka kebiasaan tersebut akan berlanjut sampai dewasa ${ }^{29}$.

\section{Perbedaan Pola Asuh Makan Balita berdasarkan Status Pekerjaan Ibu}

Pola asuh makan, ketersediaan pangan dan akses terhadap pangan merupakan faktor-faktor yang mempengaruhi status gizi serta proses pertumbuhan dan perkembangan balita. Balita yang mendapat pola asuh makan tepat akan tercukupi kebutuhannya sehingga proses pertumbuhan dan perkembangan dapat belangsung secara optimal. Balita yang mendapat pola asuh makan kurang tepat dapat menyebabkan kekurangan zat gizi yang bersifat irreversible. Pola asuh makan penting untuk diperhatikan agar balita mendapatkan asupan makan yang berkualitas.

Hasil uji T Independent terhadap pola asuh makan balita memperoleh nilai $p=0,605$ atau $p>0,05$ sehingga secara statistik tidak terdapat perbedaan pola asuh makan yang signifikan. Tabel 2 menunjukan bahwa pola asuh makan balita seluruhnya termasuk kategori tepat. Penilaian pola asuh makan dilakukan dengan menjumlahkan skor dari seluruh pertanyaan dan ditentukan persentasenya. Pola asuh makan dikatakan tepat apabila diperoleh hasil 55\%-100\%, dan kurang tepat apabila diperoleh hasil $<55 \%{ }^{30}$. Ibu memiliki peran penting dalam mengasuh balita termasuk mengatur pola konsumsi makan balita dan keluarga, akan tetapi dalam melakukan peran 
tersebut ibu dapat dibantu oleh orang dewasa yang memiliki kemampuan mendidik balita ${ }^{31}$.

Ibu tetap dapat memantau apakah perkembangan balita sudah sesuai dengan tahapan perkembangan yang seharusnya atau tidak, sehingga proses pertumbuhan dan pekembangan balita dapat tetap optimal sekalipun ibu tersebut bekerja ${ }^{31}$. Tingkat pendidikan ibu yang sebagian besar tergolong pendidikan tinggi juga akan membantu ibu dalam mengetahui makanan yang baik bagi balita dan kemudian meneruskan informasi tersebut kepada orang yang mengasuh balita, serta memantau apakah informasi tersebut diterapkan atau tidak ${ }^{32}$. Penelitian lain di Boyolali menunjukan bahwa pekerjaan ibu tidak berhubungan dengan pemberian stimulus maupun pola asuh makan pada balita berusia 2-5 tahun ${ }^{31}$. Pola asuh makan batita yang diasuh ibu dan selain ibu tidak memiliki perbedaan yang signifikan karena tingkat pendapatan keluarga dan pendidikan ibu yang sama-sama tinggi ${ }^{32}$.

\section{Perbedaan Asupan Zat Gizi Makro Balita berdasarkan Status Pekerjaan Ibu}

Uji $\mathrm{T}$ Independent terhadap asupan energi memperoleh nilai $p=0,483$ atau $p>0,05$ sehingga secara statistik tidak terdapat perbedaan asupan energi yang signifikan. Hal tersebut dikarenakan pada balita dari kedua kelompok ratarata asupan energinya relatif sama, yaitu $108,8 \%$ dan $104,1 \%$. Seorang ibu, baik ibu rumah tangga atau bekerja sebagai pegawai memiliki kesadaran yang sama untuk mencukupi kebutuhan zat gizi balita, sehingga akan tetap memberikan perhatian terhadap pemberian makan balitanya, walaupun pada ibu bekerja memerlukan bantuan oranglain untuk melakukannya ${ }^{31}$.

Hasil uji T Independent terhadap asupan protein memperoleh nilai $p=0,806$ atau $p>0,05$ sehingga secara statistik tidak terdapat perbedaan asupan protein yang signifikan. Hal tersebut dikarenakan pada balita dari kedua kelompok ratarata asupan proteinnya relatif sama, yaitu $209,8 \%$ dan 206,4\%. Menurut AKG tahun 2019, rata-rata kebutuhan protein balita dalam sehari yaitu sebesar 20-25 gram, sedangkan temuan di lapangan ratarata asupan protein pada balita dari ibu bekerja dan ibu rumah tangga yaitu 39,6 gram dan 38,5 gram dalam sehari.

Asupan protein yang tinggi pada balita selain bersumber dari makanan utama juga diperoleh dari susu formula. Asupan protein pada balita dari ibu bekerja yang bersumber dari susu formula sebesar $71,7 \%$ dari total kebutuhan protein dalam sehari dan $65,4 \%$ pada balita dari ibu tidak bekerja. Pemberian susu formula sebaiknya diberikan sebagai makanan selingan dan tidak menggantikan makanan utama.

Hasil uji T Independent terhadap asupan lemak memperoleh nilai $p=0,787$ atau $p>0,05$ sehingga secara statistik tidak terdapat perbedaan asupan lemak yang signifikan. Hal tersebut dikarenakan pada balita dari kedua kelompok rata-rata asupan lemaknya relatif sama, yaitu $130,6 \%$ dan $128 \%$. Sumber asupan lemak pada responden diantaranya dari bahan makanan sumber protein yang tinggi lemak, minyak yang digunakan untuk memasak, dan susu formula. Susu formula menyumbang lemak pada balita dari ibu bekerja sebesar $45,5 \%$ dan ibu tidak bekerja sebesar $35,3 \%$ dari total kebutuhan lemak dalam sehari. Asupan lemak berlebih terutama lemak jenuh dalam jangka panjang dapat memicu terjadinya obesitas. Resiko obesitas meningkat 4,4 kali lebih besar pada anak dengan tingkat asupan lemak yang termasuk dalam kategori lebih ${ }^{33}$.

Hasil uji T Independent terhadap asupan karbohidrat memperoleh nilai $p=0,337$ atau $p>0,05$ sehingga secara statistik tidak terdapat perbedaan asupan karbohidrat yang signifikan. Hal tersebut dikarenakan rata-rata asupan karbohidrat pada balita relatif sama, yaitu $86,4 \%$ dan $80,9 \%$. Sumber karbohidrat diantaranya terdiri dari berbagai jenis makanan pokok, sayur dan buah. Hasil penelitian ini menunjukan sebagian besar karbohidrat yang dikonsumsi balita berasal dari makanan pokok seperti nasi, biskuit, roti, dan berbagai olahan tepung terigu lainnya. Asupan karbohidrat yang rendah pada penelitian ini disebabkan karena konsumsi makanan pokok seperti nasi, serta sayur dan buah yang rendah, selain itu juga dikarenakan jumlah konsumsi makanan sumber karbohidrat lebih sedikit dibandingkan makanan sumber protein. Kekurangan asupan karbohidrat dalam tubuh akan mengakibatkan terjadinya proses pemecahan glikogen (glikolisis) dan dalam jangka panjang dapat mempengaruhi status gizi seseorang ${ }^{34}$.

\section{KESIMPULAN}

Responden pada penelitian ini sebagian besar berusia 12-23 bulan dan memiliki status gizi baik. Tidak terdapat perbedaan keragaman pangan, pola asuh makan, dan asupan zat gizi makro pada balita berdasar status pekerjaan ibu.

\section{ACKNOWLEDGEMENT}

Peneliti mengucapkan terimakasih kepada Lembaga Penelitian dan Pengabdian Kepada Masyarakat (LPPM) Universitas Jenderal Soedirman yang telah memberikan pendanaan dalam penelitian ini. Kepala Desa Karangsalam, Bidan Desa serta Kader Posyandu Perumahan Grand Safira Karang Salam dan Saphire Regency Karang Sempu Purwokerto atas izin dan dukungannya sehingga penelitian ini dapat terlaksana. Terimakasih juga peneliti sampaikan kepada ibu balita yang telah mengizinkan balitanya menjadi responden pada penelitian ini, serta seluruh pihak yang terlibat sehingga penelitian ini berjalan dengan lancar.

\section{REFERENS}

1. Tarigan, I. U. Faktor-Faktor yang Berhubungan dengan Status Gizi Anak Umur 6-36 Bulan Sebelum dan Saat Krisis Ekonomi di Jawa Tengah. Bul. Penelit. Kesehat. 31, 1-12 (2003).

2. Kementerian Kesehatan. Profil Kesehatan Indonesia 2018. https://pusdatin.kemkes.go.id/resources/downl 
oad/pusdatin/profil-kesehatanindonesia/PROFIL_KESEHATAN_2018_1.pdf (2018).

3. Pemantauan Status Gizi. Buku Saku Pemantauan Status Gizi Tahun 2017. (Kementerian Kesehatan Republik Indonesia, 2017).

4. Soetjiningsih. Tumbuh Kembang Anak. (Penerbit Buku Kedokteran EGC, 1995).

5. Badan Pusat Statistik. Keadaan Ketenagakerjaan Indonesia Februari 2019. (Badan Pusat Statistik Indonesia, 2019).

6. Dyah, A. S. Hubungan Antara Pengetahuan Ibu Tentang Makanan Bergizi Dengan Status Gizi Balita Usia 1-3 Tahun Didesa Lencoh Wilayah Kerja Puskesmas Selo Boyolali. Publ. Penelitian, Akbid Estu Utomo, Boyolali (2008).

7. Abdiana. Hubungan Durasi Pemberian ASI dengan Kejadian Kegemukan pada Anak Taman Kanak-Kanak di Wilayah Kerja Puskesmas Lubuk Buaya Kota Padang tahun 2010. (2010).

8. Sarah, M. Hubungan Tingkat Sosial Ekonomi dan Pola Asuh dengan Status Gizi Anak Balita di Wilayah Kerja Puskesmas Pantai Cermin Kecamatan Tanjung Pura Kabupaten Langkat Tahun 2008. (Universitas Sumatera Utara, 2008).

9. Pratiwi, T. D., Masrul \& Eti, Y. Hubungan Pola Asuh Ibu dengan Status Gizi Balita di Wilayah Kerja Puskesmas Belimbing Kota Padang. J. Kesehat. Andalas 5, 661-665 (2016).

10. Undang-undang Ketenagakerjaan. Undangundang Republik Indonesia Nomor 13 Tahun 2003. (2003).

11. Diana, F. M. Hubungan Pola Asuh dengan Status Gizi Kelurahan Pasar Ambacang Kota Padang Tahun 2004. J. Kesehat. Masy. 1, 19-23 (2006).

12. Food and Agriculture Organization. Guidelines for Measuring Household and Individual Dietary Diversity. 2010.

13. Labadarios, D., Zandile, J., Gericke, G., Eleni, M. \& Paker, W. Food security in South Africa: a review of national surveys. Bull World Heal. Organ 891-899 (2011).

14. Widyaningsih, N. N., Kusnandar \& Anantanyu, S. Keragaman pangan, Pola Asuh Makan dan Kejadian Stunting pada Balita Usia 24-59 Bulan. J. Gizi Indones. 7, 22-29 (2018).

15. Almatsier, S. Prinsip Dasar Ilmu Gizi. (Gramedia Pustaka Utama, 2010).

16. Helmi, R. Faktor-faktor yang Berhubungan dengan Status Gizi pada Balita di Wilayah Kerja Puskesmas Margototo Kecamatan Metro Kibang Kabupaten Lampung. J. Kesehat. IV, 233-242 (2013).

17. Barasi, M. Nutrition at a Glance. (Erlangga, 2007).

18. World Health Organization. Indicators for assessing infant and young child feeding practices part 3: country profiles. WHO Press. Geneva (2002).

19. Kementerian Kesehatan Republik Indonesia. Peraturan Menteri Kesehatan Republik Indonesia
Nomor 2 Tahun 2020 tentang Standar Antropometri Anak. (2020).

20. Krieger, N., D.R., W. \& N.E., M. Measuring social class in US public health research: concepts, methodologies, and guidlines. Annu Rev Public Heal. 18, 41-78 (1997).

21. Krisnatutu, D. Menyiapkan Makanan Pendamping Air Susu Ibu. (Puspa Swara, 2001).

22. Wirawan, N. N. \& Rahmawati, W. Ketersediaan dan Keragaman Pangan serta Tingkat Ekonomi sebagai Prediktor Status Gizi Balita. Indones. J. Hum. Nutr. 3, 80-90 (2016).

23. Bezerra, I. N. \& Sichieri, R. Household food diversity and nutritional status among adults in Brazil. Int. J. Behav. Nutr. Phys. Act. 8, (2011).

24. Rahardjo, S. \& Wijayanti, S. P. M. Peran Ibu yang Berhubungan dengan Peningkatan Status Gizi Balita (Studi di Wilayah Puskesmas II Sumbang Kabupaten Banyumas). J. Kesmas Indones. 3, 5666 (2010).

25. Grober, U. Penyelarasan Metabolik, Pencegahan dan Terapi. (Penerbit Buku Kedokteran EGC, 2009).

26. Afif, P. A. \& Sri, S. Peran Ibu sebagai Edukator dan Inisiator Konsumsi Sayur Buah pada Anak. Amerta Nutr. 1, 236-242 (2017).

27. Waladow, G., Sarah, M. \& Jula, V. . Hubungan Pola Makan dengan Status Gizi pada Anak usia 35 Tahun di Wilayah Kerja Puskesmas Tompaso Kecamatan Tompaso. ejournal Keperawatan 1, 1-6 (2013).

28. Marlinda, P. Pola Konsumsi Buah dan Sayur Anak Usia 4-6 Tahun pada Masyarakat Pesisir Desa RanduSanga Kulon Brebes. (Universitas Negeri Semarang, 2016).

29. Kurniawati, T. \& Wahono, N. S. Pola Konsumsi Buah dan Sayur pada Anak Usia Dini sebagai Usaha Penanggulangan Penyakit Kanker. J. Anak Usia Dini dan Pendidik. Anak Usia Dini 3, 221226 (2017).

30. Camci, N., Bas, M. \& H., A. B. The Psychometric Properties of the Child Feeding Questionare (CFQ) in Turkey. Appetite 78, 49-54 (2014).

31. Putri, D. F. T. P. \& Kusbaryanto. Perbedaan Hubungan antara Ibu Bekerja dan Ibu Rumah Tangga terhadap Tumbuh Kembang Anak Usia 25 Tahun. Mutiara Med. 12, 143-149 (2012).

32. Sari, P. N. \& Sumarmi, S. Perbedaan Pola Pemberian Makan Batita Diasuh Ibu dan Selain Ibu. Amerta Nutr. 98-104 (2017) doi:10.20473/amnt.v1.i2.2017.98-104.

33. Kharismawati, R. Hubungan Tingkat Asupan Energi, Protein, Lemak, Karbohidrat, dan Serat dengan Status Obesitas Pada Siswa SD. SKRIPSI (Universitas Diponegoro, Semarang, 2010).

34. Baculu, E. P. H. Hubungan Pengetahuan Ibu dan Asupan Karbohidrat dengan Status Gizi pada Anak Balita di Desa Kalangkangan Kecamatan Galang Kabupaten Tolitoli. Promotif 7, 14-17 (2017). 